\title{
MICROSTRUCTURAL CHANGES OF THE NANOSTRUCTURED BAINITIC STEEL INDUCED BY QUASI-STATIC AND DYNAMIC DEFORMATION
}

\begin{abstract}
Changes in the microstructure of nanostructured bainitic steel induced by quasi-static and dynamic deformation have been shown in the article. The method of deformation and strain rate have important impact on the microstructure changes especially due to strain localization. Microstructure of nanostructured steel Fe- $0.6 \% \mathrm{C}-1.9 \mathrm{Mn}-1.8 \mathrm{Si}-1.3 \mathrm{Cr}-0.7 \mathrm{Mo}$ consists of nanometer size carbide-free bainite laths and $20-30 \%$ volume fraction of retained austenite. Quasi-static and dynamic (strain rate up to $2 \times 10^{2} \mathrm{~s}^{-1}$ ) compression tests were realized using Gleeble simulator. Dynamic deformation at the strain rate up to $9 \times 10^{3} \mathrm{~s}^{-1}$ was realized by the Split Hopkinson Pressure Bar method (SHPB). Moreover high energy firing tests of plates made of the nanostructured bainitic steel were carried out to produce dynamically deformed material for investigation. Adiabatic shear bands were found as a result of localization of deformation in dynamic compression tests and in firing tests. Microstructure of the bands was examined and hardness changes in the vicinity of the bands were determined. The TEM examination of the ASBs showed the change from the internal shear band structure to the matrix structure to be gradual. This study clearly resolved that the interior (core) of the band has an extremely fine grained structure with grain diameter ranging from $100 \mathrm{~nm}$ to $200 \mathrm{~nm}$. Martensitic twins were found within the grains. No austenite and carbide reflections were detected in the diffraction patterns taken from the core of the band. Hardness of the core of the ASBs for examined variants of isothermal heat treatment was higher about $300 \mathrm{HV}$ referring to steel matrix hardness.

Keywords: nanostructured bainitic steel, dynamic deformation, adiabatic shear bands, transmission electron microscopy
\end{abstract}

\section{Introduction}

Steel grades with microstructure consisting of nanometre size carbide-free bainite laths and retained austenite (nanostructured bainite) offers an unique combination of ultra-high strength and good ductility [1-5]. The nanostructured bainitic steels have been proposed for production of plates, sheets and bars for applications demanding ultra-high strength and good ductility, and also high level of other properties such as wear resistance [6], fatigue strength [7] or ballistic protection [8,9].

During dynamic deformation of steels at high strain rates the frequently formation of narrow zones of highly localized deformation known as adiabatic shear bands (ASBs) occurring. Shear bands have been observed in variety of materials used for machining, ballistic impact, high-velocity forming etc. The bands arising from localization of deformation occur more readily in materials with low work hardening rate, low strain rate sensitivity, low thermal conductivity and high thermal softening rate. Shear bands have been classified into two types: deformed bands and transformed bands, the latter suggestive of a phase transformation having occurred within the band during its formation. The transformation is thought to be austenite to martensite, due to quenching by the surrounding colder matrix of the steel although all evidence to date is indirect. Transformed bands in steels may be as narrow as 5-10 $\mu \mathrm{m}$ and will appear white after nital etching. Deformed bands in steels are generally broad and do not etch white [10,11].

Shear localization has been found to be an important and sometimes dominant deformation and fracture mode in metals. Fielding and Bhadeshia examined shear bands generated in the carbide-free bainitic steel by ballistic testing [12]. The authors suggested that the bands consist of deformed layers in which the original structure becomes mechanically mixed, and resembles a warm-worked microstructure that is still in an unrecrystallised state. Moreover their observations show that the bands are unlikely to represent phase transformation from austenite that forms during adiabatic heating and transforms subsequently into martensite [12]. Meyers et al. analysed the microstructural processes occurring in the different classes of materials deformed at high strain rates. They found that thermal softening is the first stage of shear localization process, leading to processes of dynamic recovery and recrystallization with associated drops in the flow stress [13]. Microstructure and hardness of adiabatic shear bands in ballistically tested plates made of nanostructured bainitic steel and maraging steel were examined by Garbarz et al. [14]. They found white-etched adiabatic shear bands with

\footnotetext{
* INSTITUTE FOR FERROUS METALLURGY, UL. KAROLA MIARKI 12-14, 44-100 GLIWICE

** MILITARY UNIVERSITY OF TECHNOLOGY, UL. GEN. SYLWESTRA KALISKIEGO 2, 01-476 WARSZAWA
}

\# Corresponding author: jmarcisz@imz.pl 
microcracks within in the deformation areas. Average hardness of adiabatic shear bands in bainitic steel was higher than hardness of matrix of this steel while in maraging steel an opposite effect was found - average hardness of adiabatic shear bands was lower than hardness of matrix of this steel [14]. Chung et al. carried out numerical and experimental study of the formation of adiabatic shear bands in the 4340 steel grade deformed using Split Hopkinson Pressure Bar. The authors found out very sharp adiabatic shear bands apparently formed by localized deformation. Overall shape and direction of the bands coincided with results of the numerical calculation [15].

In this work propensity for adiabatic shear bands formation (an associated microstructural evolution) under quasi-static and dynamic deformation in nanostructured bainitic steel have been studied. Microstructure of the bands formed during different test conditions (compression, firing) were examined and hardness of the bands were determined.

\section{Material and experimental procedures}

\subsection{Material}

Industrial heat of nanostructured bainitic steel with chemical composition showed in the Table 1 was melted in an electric arc furnace. The ingots were homogenised at $1200^{\circ} \mathrm{C}$ during 24 hours and next they were hot forged into flat transfer bars for hot rolling. Plates with thickness 3, 5, 6, 8, 10 and $12 \mathrm{~mm}$ were hot rolled. Next for the final heat treatment and for further investigation were cut out. The heat treatment process consisted of austenitising and direct controlled cooling to a temperature of the isothermal heat treatment. Subsequently isothermal transformation into lower bainite at a temperature in the range of $210 \div 275^{\circ} \mathrm{C}$ during a period of time in the range of $70 \div 120$ hours was carried out.

For investigation of deformation behavior of nanostructured bainitic steel in quasi-static and dynamic compression tests, two variants of isothermal heat treatment were chosen. The variants of isothermal transformation temperatures (ITT): $210^{\circ} \mathrm{C}$ and $275^{\circ} \mathrm{C}$, characterized by different mechanical properties and microstructure, especially volume fraction of retained austenite.

TABLE 1

Chemical composition of nanostructured bainitic steel, $\mathrm{wt} \%$

\begin{tabular}{|c|c|c|c|c|c|c|c|}
\hline \hline C & Mn & Si & Cr & Mo & Cu & P & S \\
\hline 0.59 & 2.04 & 1.90 & 1.32 & 0.71 & 0.12 & 0.009 & 0.004 \\
\hline
\end{tabular}

In Table 2 mechanical properties for selected final heat treatment parameters are shown. For the obtained values of strength: 1.6 and $2.0 \mathrm{GPa}$, a high level of ductility up to $19 \%$ and $12 \%$ respectively as expressed by the total elongation in tensile test and Charpy-V impact toughness $24 \mathrm{~J}$ at room temperature should be emphasised.

In the as-received condition (after isothermal heat treatment and before deformation tests) the steel has a laths carbide free bainite microstructure with uniformly distributed blocky austenite grains (Fig. 1). Under high magnification examination in a transmission electron microscope (TEM), microstructure of the plates was seen to be composed of nano-laths of carbideless bainite with high density of dislocations and films of retained austenite (Fig. 2).

TABLE 2

Mechanical properties, hardness and retained austenite content of nanostructured steel

\begin{tabular}{|c|c|c|c|c|c|c|c|c|}
\hline \hline $\begin{array}{c}\text { Temperature of } \\
\text { isothermal heat } \\
\text { treatment }\end{array}$ & $\begin{array}{c}\text { Yield Stress, } \\
\mathbf{M P a}\end{array}$ & $\begin{array}{c}\text { Ultimate } \\
\text { Tensile Stress, } \\
\mathbf{M P a}\end{array}$ & $\begin{array}{c}\text { Total } \\
\text { elongation, } \\
\mathbf{\%}\end{array}$ & $\begin{array}{c}\text { Uniform } \\
\text { elongation, } \\
\mathbf{\%}\end{array}$ & $\begin{array}{c}\text { Hardness, } \\
\mathbf{H V 1 0}\end{array}$ & \multicolumn{2}{|c|}{$\begin{array}{c}\text { Charpy-V impact toughness, } \\
\mathbf{J}\end{array}$} & $\begin{array}{c}\text { Volume fraction } \\
\text { of retained } \\
\text { austenite, } \mathbf{\%}^{\mathbf{2}}\end{array}$ \\
\hline $\mathbf{2 1 0}^{\circ} \mathbf{C}$ & 1300 & 2050 & 12 & 10 & $610-630$ & 23 & 13 & $20.4 \pm 0.7$ \\
\hline $\mathbf{2 7 5}^{\circ} \mathbf{C}$ & 1200 & 1650 & 19 & 15 & $530-550$ & 24 & 14 & $31.5 \pm 0.4$ \\
\hline
\end{tabular}

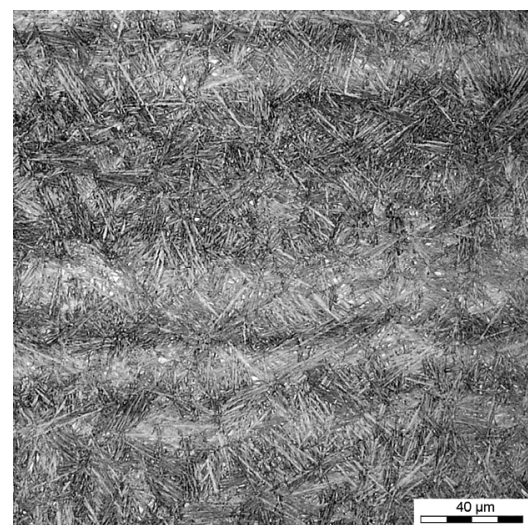

(a)

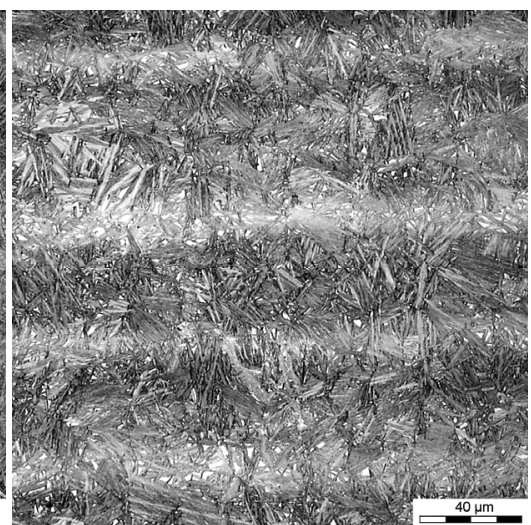

(b)

Fig. 1. Microstructure of nanostructured bainitic steel after isothermal heat treatment at $210^{\circ} \mathrm{C}$ (a) and $275^{\circ} \mathrm{C}$ (b) in the as-received condition before deformation, light microscope 


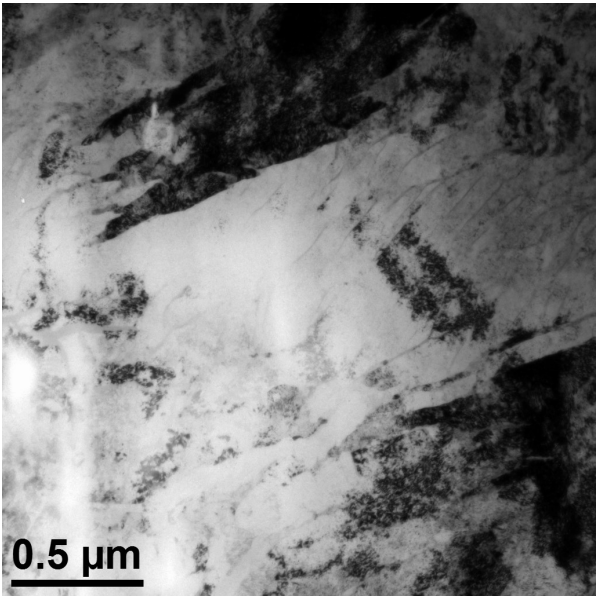

(a)

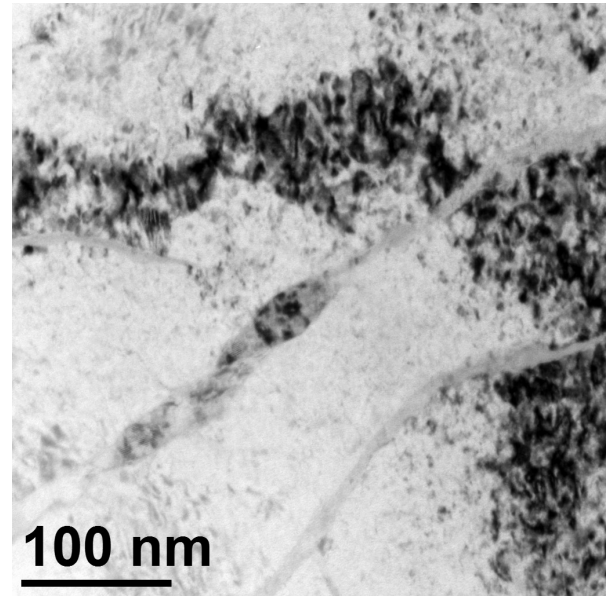

(b)

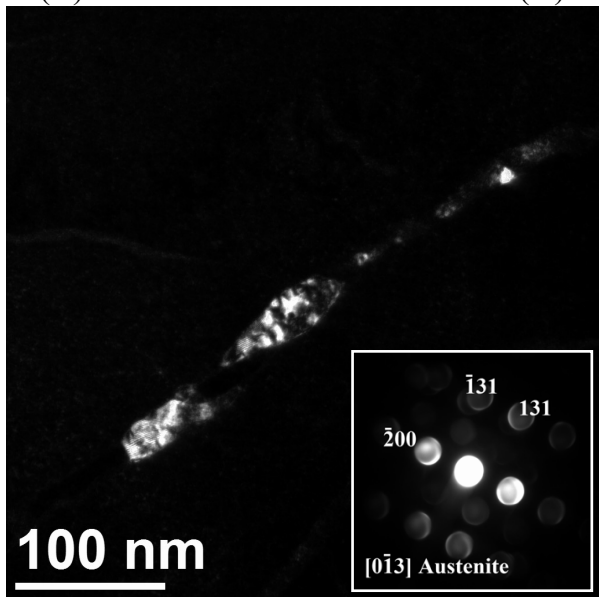

(c)

Fig. 2. Bright field TEM images (a, b), dark field TEM image in 131 reflection and electron diffraction pattern for the zone axis [0-13] taken from the film of austenite (c). Isothermal transformation temperature: $210^{\circ} \mathrm{C}$

\subsection{Experimental procedure}

\subsubsection{Quasi - static and dynamic deformation experiments in Gleeble simulator}

Quasi-static and dynamic uniaxial compression tests were carried out in Gleeble simulator. For specimens of dimension $\phi 6 \times 7 \mathrm{~mm}$ used in experiments, maximum strain rate about $200 \mathrm{~s}^{-1}$ was obtained. For tests realized in Gleeble, two variants of ITT $\left(210^{\circ} \mathrm{C}\right.$ and $\left.275^{\circ} \mathrm{C}\right)$ and two strain rate values $\left(0.5 \mathrm{~s}^{-1}\right.$ and $200 \mathrm{~s}^{-1}$ ) were chosen. Compression stress-strain curves at nominal strain rates $0.5 \mathrm{~s}^{-1}$ and $200 \mathrm{~s}^{-1}$ are shown in Fig. 3 . At the low strain rate $0.5 \mathrm{~s}^{-1}$ high strength level was obtained $2.2 \mathrm{GPa}$ and $2.8 \mathrm{GPa}$ at strain 1.0 and 0.6 for ITT $275^{\circ} \mathrm{C}$ and $210^{\circ} \mathrm{C}$ respectively, however quasi-static hardening rates were similar for both variants.

Deformation at the strain rate $200 \mathrm{~s}^{-1}$ causes the yield stress increasing but the maximum stresses in compression were similar or slightly lower in comparison to the tests at the strain rate $0.5 \mathrm{~s}^{-1}$. Moreover strain value for the specimens deformed at strain rate $200 \mathrm{~s}^{-1}$ was about 0.5 and 0.3 for ITT $275^{\circ} \mathrm{C}$ and $210^{\circ} \mathrm{C}$ respectively.

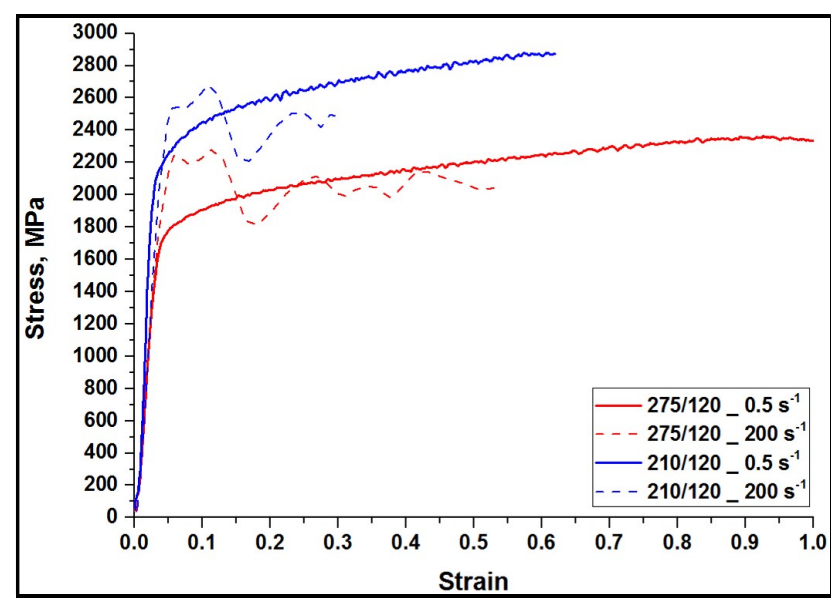

Fig. 3. Engineering stress-strain curves of nanostructured bainitic steel compressed using Gleeble simulator

\subsubsection{Dynamic deformation experiments in Split Hopkinson Pressure Bar tests}

Dynamic response of the nanostructured bainitic steel was analysed using Split Hopkinson Pressure Bar (SHPB) method. Experiments were carried out using specimens of dimensions 
$\phi 4 \times 4 \mathrm{~mm}$ and $\phi 4 \times 2 \mathrm{~mm}$. Parameters of the dynamic compression tests realized using SHPB are presented in Table 3. Representative dynamic stress-strain curves for the selected variants of the nanostructured bainitic steels are compared in Fig. 4. Depending on isothermal transformation temperature (ITT) and strain rate, two levels of strength were obtained. ITT $275^{\circ} \mathrm{C}$ and $210^{\circ} \mathrm{C}$ variants of nanostructured bainitic steel reached maximum stress in dynamic compression about 2.0 GPa and 2.6 GPa respectively. Characteristic behavior of low strain-rate independent work hardening was observed for both variants of nanostructured steel. Localization event as seen by the precipitous drop in stress at strains corresponding to about $15-25 \%$ for ITT $210^{\circ} \mathrm{C}$ variant was detected. Note that stresses as high as 2.5-2.6 GPa are supported prior to localization. The localization effect was not detected for ITT $275^{\circ} \mathrm{C}$ variant of the steel.

TABLE 3

Parameters of dynamic compression tests realized using Split Hopkinson Pressure Bar

\begin{tabular}{|c|c|}
\hline \hline $\begin{array}{c}\text { Isothermal transformation } \\
\text { temperature (ITT), }{ }^{\circ} \mathbf{C}\end{array}$ & Strain rate, $\mathbf{s}^{\mathbf{- 1}}$ \\
\hline \multirow{2}{*}{210} & 2266 \\
\cline { 2 - 2 } & 3830 \\
\cline { 2 - 2 } & 4306 \\
\hline \multirow{2}{*}{275} & 5138 \\
\cline { 2 - 2 } & 6585 \\
\cline { 2 - 2 } & \\
\hline
\end{tabular}

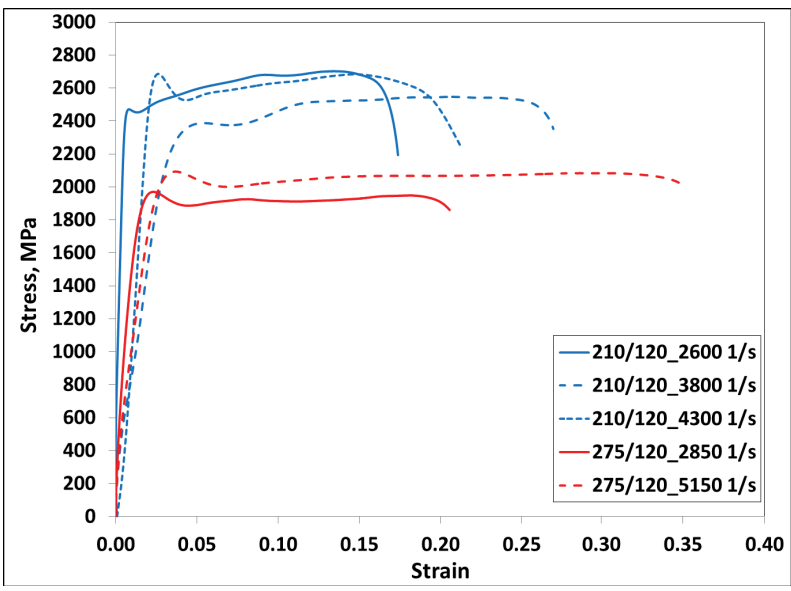

Fig. 4. Stress-strain curves of nanostructured bainitic steel dynamically compressed using SHPB

\subsubsection{Firing tests}

Plates of thickness $6 \mathrm{~mm}$ and $8 \mathrm{~mm}$ made of the nanostructured bainitic steel isothermal heat treated at $210^{\circ} \mathrm{C}$ were used in firing tests. Plates were tested with $0^{\circ}$ and $30^{\circ}$ obliquity (angle between normal to the plate and firing direction). Specimens were mounted on the rigid stand with the distance from barrel of $10 \mathrm{~m}$ and $30 \mathrm{~m}$. For tests with $0^{\circ}$ obliquity the distance was $10 \mathrm{~m}$ and for firing with $30^{\circ}$ obliquity the distance was $30 \mathrm{~m}$. Three types of ammunition were used in firing tests. Types of ammunition characterize of different ability to steel plate penetration depended on dimension, shape and hardness of the core, velocity and impact energy of projectile. The velocity of the projectiles was changed by designed amount of gunpowder. Projectile velocity was measured during the tests using precision chronograph. Firing test parameters are shown in Table 4.

TABLE 4

Firing test parameters of plates made of nanostructured bainitic steel

\begin{tabular}{|c|c|}
\hline $\begin{array}{c}\text { Plate } \\
\text { thickness }\end{array}$ & Test parameters \\
\hline $8 \mathrm{~mm}$ & $\begin{array}{c}\text { Firing test (one shot) } 0^{\circ} \text { obliquity } \\
\text { Projectile velocity (energy): } 766 \mathrm{~m} / \mathrm{s} ;(2280 \mathrm{~J})\end{array}$ \\
\hline $8 \mathrm{~mm}$ & $\begin{array}{c}\text { Firing test (one shot) } 0^{\circ} \text { obliquity } \\
\text { Projectile velocity (energy): } 929 \mathrm{~m} / \mathrm{s} ;(1536 \mathrm{~J})\end{array}$ \\
\hline $8 \mathrm{~mm}$ & $\begin{array}{c}\text { Firing test (multihit }-5 \text { shots in one point) } \\
30^{\circ} \text { obliquity, projectile velocity (energy): } \\
850-870 \mathrm{~m} / \mathrm{s} ;(3421-3577 \mathrm{~J})\end{array}$ \\
\hline $6 \mathrm{~mm}$ & $\begin{array}{c}\text { Firing test (multihit }-5 \text { shots in one point), } \\
30^{\circ} \text { obliquity, projectile velocity (energy): } \\
836-844 \mathrm{~m} / \mathrm{s} ;(3258-3319 \mathrm{~J})\end{array}$ \\
\hline
\end{tabular}

\section{Examination results of ASB's microstructure}

\subsection{Light microscopy}

Representative images of adiabatic shear bands in quasistatically and dynamically deformed nanostructured bainitic steel in Gleeble simulator are shown in Figs. 5 and 6. ASBs of width up to $10 \mu \mathrm{m}$ for ITT $210^{\circ} \mathrm{C}$ variant were found at strain rate $0.5 \mathrm{~s}^{-1}$. For the same variant of final heat treatment ASBs of width up to $40 \mu \mathrm{m}$ were found at strain rate $200 \mathrm{~s}^{-1}$. First ASBs for ITT $275^{\circ} \mathrm{C}$ variant were observed in specimen compressed at strain rate $200 \mathrm{~s}^{-1}$. Angle between the bands and direction of compression was between 40 and $50^{\circ}$ for all tests realized in Gleeble.

Very thin (width below $5 \mu \mathrm{m}$ ) adiabatic shear bands in dynamically compressed specimen of ITT $210^{\circ} \mathrm{C}$ variant using SHPB at strain rate up to $3830 \mathrm{~s}^{-1}$ were observed (Fig. 7a,b). For higher strain rate $\left(4300 \mathrm{~s}^{-1}\right)$ in SHPB test adiabatic shear bands of width 5-10 $\mu \mathrm{m}$ were found (Fig. 7c). Ability for ASBs formation for variant ITT $275^{\circ} \mathrm{C}$ was considerably lower in comparison with ITT $210^{\circ} \mathrm{C}$ variant. In SHPB tests the first ASBs of width below $10 \mu \mathrm{m}$ were found at maximum strain rate $8999 \mathrm{~s}^{-1}$ (Fig. 8).

Representative ASBs due to ballistic tests for ITT $210^{\circ} \mathrm{C}$ variant of nanostructured bainitic steel are shown in Figs. 9-12. Especially during firing tests with $0^{\circ}$ obliquity, numerous and wide (up to $30 \mu \mathrm{m}$ ) ASBs were formed in the near to surface layer of impact area (Figs. 9 and 10). In the firing tests at $30^{\circ}$ obliquity thin ASBs formed only in the narrow layer under impact surface (Fig. 11). Examination of the shear bands on the surface perpendicular to the projectile direction (Fig. 12) have shown distribution of the bands around impact point. The distance between the bands was in the range $20-40 \mu \mathrm{m}$. 


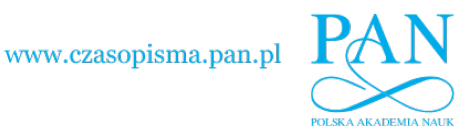

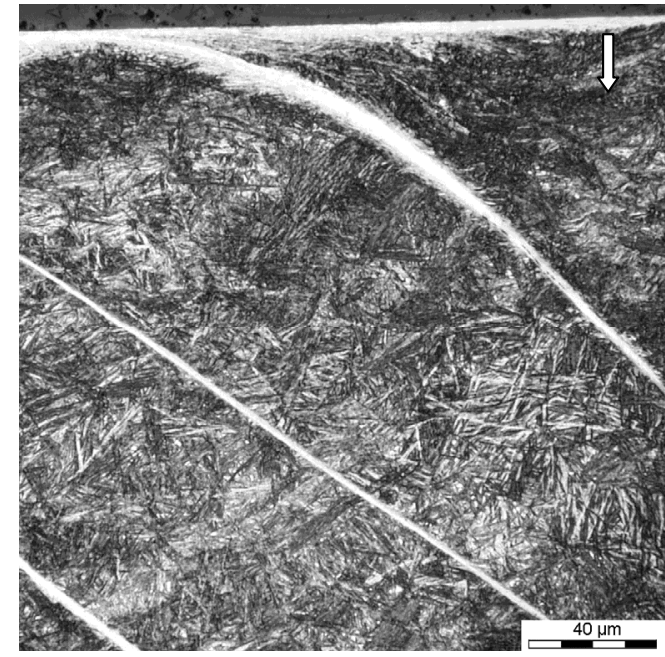

a )

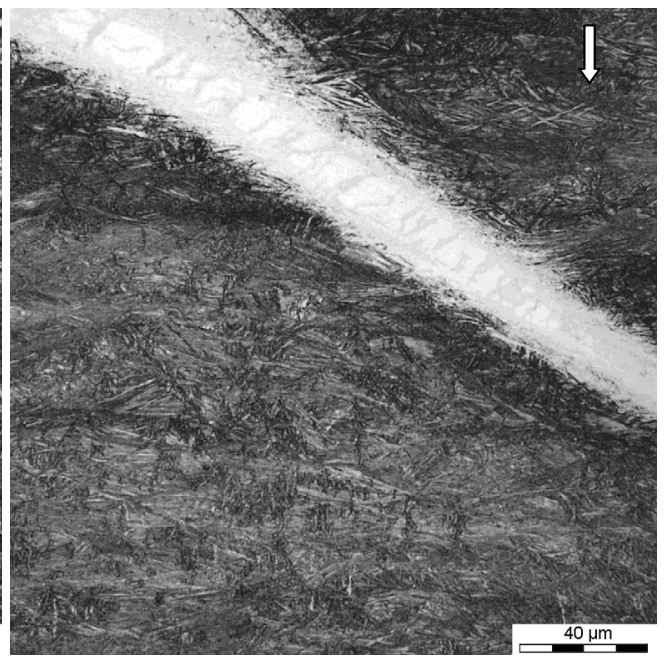

b )

Fig. 5. An adiabatic shear bands in the specimens after uniaxial compression test in Gleeble simulator. ITT $210^{\circ} \mathrm{C}$ variant. a) strain rate $0.5 \mathrm{~s}^{-1}$, b) strain rate $200 \mathrm{~s}^{-1}$. Arrows indicate the compression direction

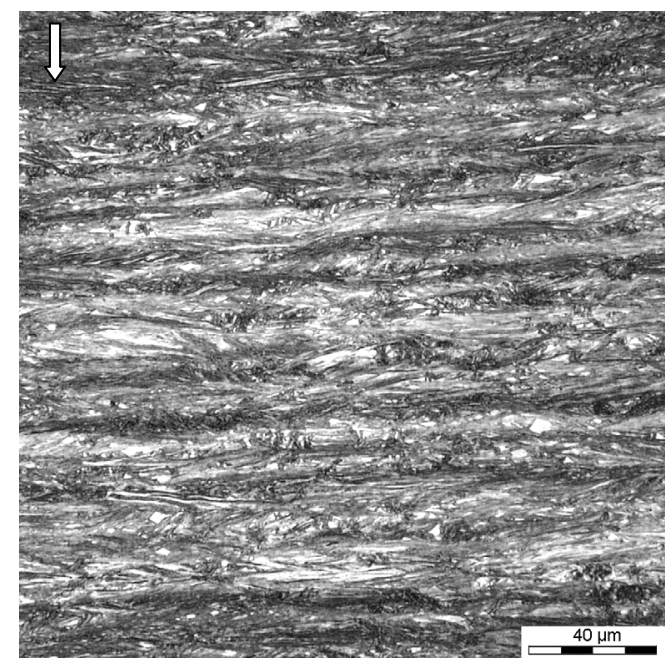

a )

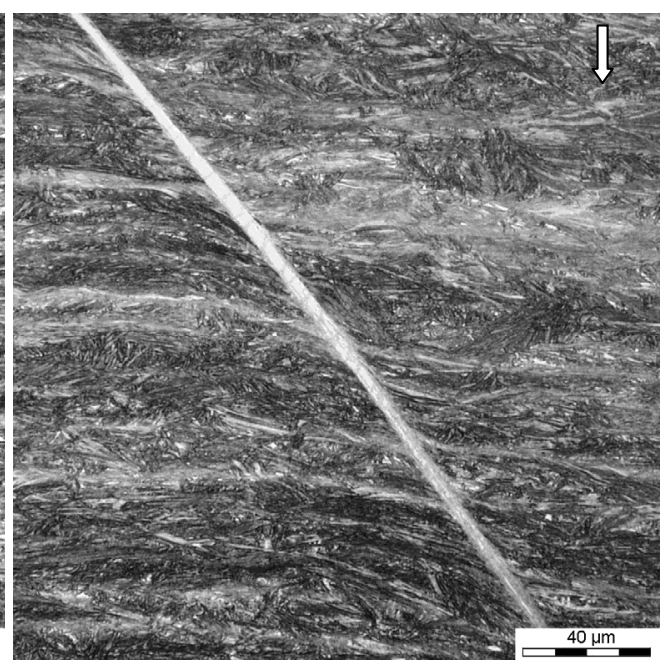

b )

Fig. 6. Microstructure of the specimens after uniaxial compression test in Gleeble simulator. ITT $275^{\circ} \mathrm{C}$ variant. a) strain rate $0.5 \mathrm{~s}^{-1}, \mathrm{~b}$ ) strain rate $200 \mathrm{~s}^{-1}$. Arrows indicate the compression direction

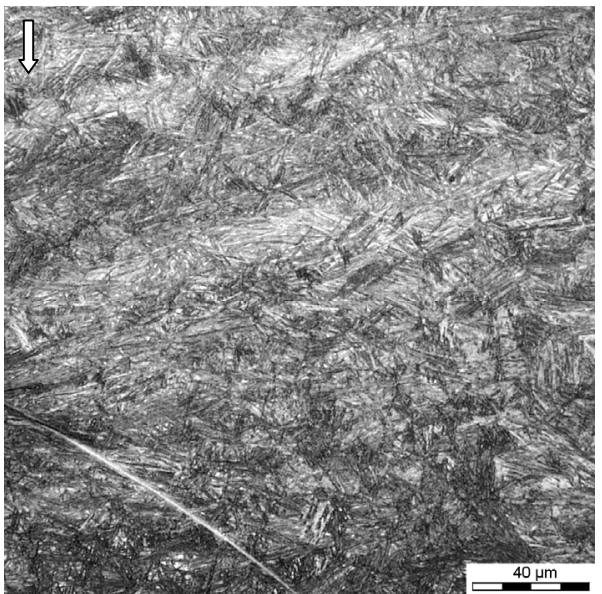

a )

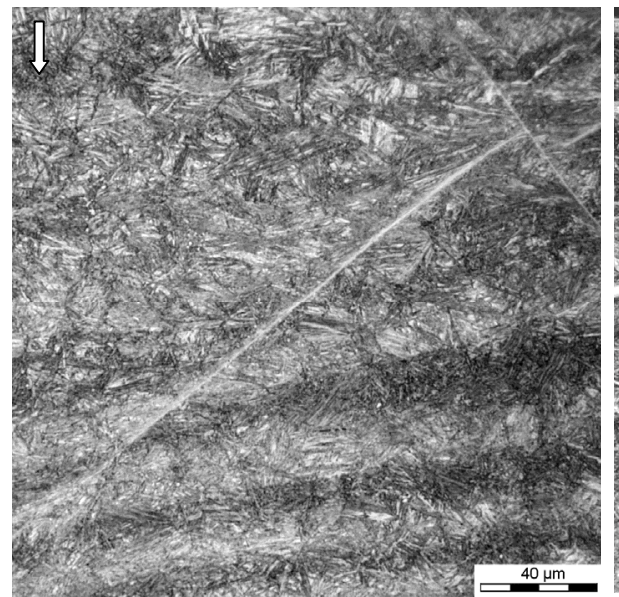

b )

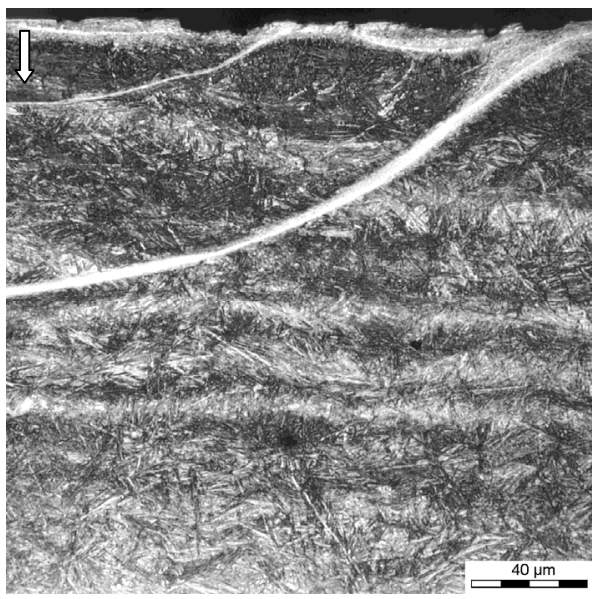

(c)

Fig. 7. An adiabatic shear bands in dynamically deformed specimens of nanostructured bainitic steel. Dynamic compression tests using SHPB. ITT $210^{\circ} \mathrm{C}$ variant: a) strain rate $2266 \mathrm{~s}^{-1}$, b) strain rate $3830 \mathrm{~s}^{-1}$, c) strain rate $4306 \mathrm{~s}^{-1}$. Arrows indicate the compression direction 


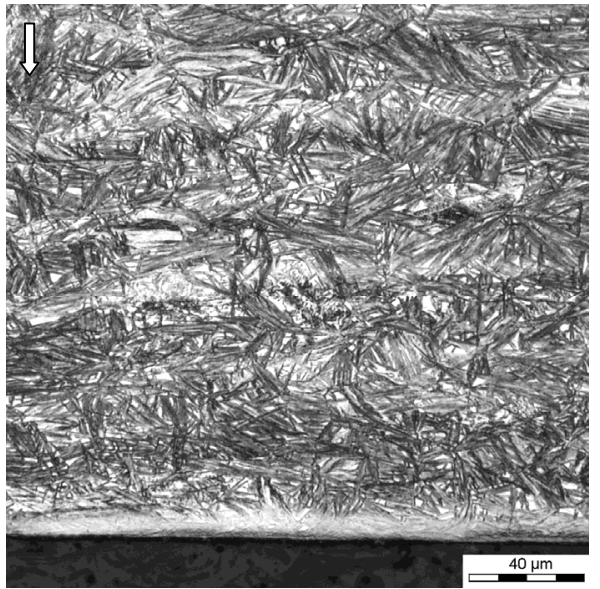

(a)

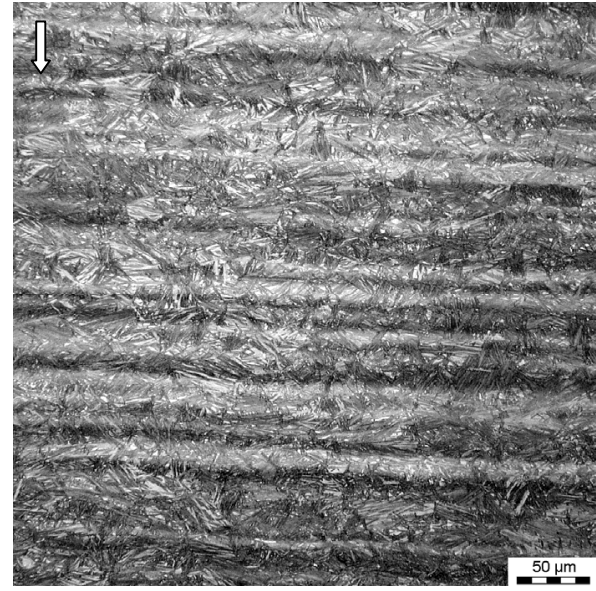

(b)

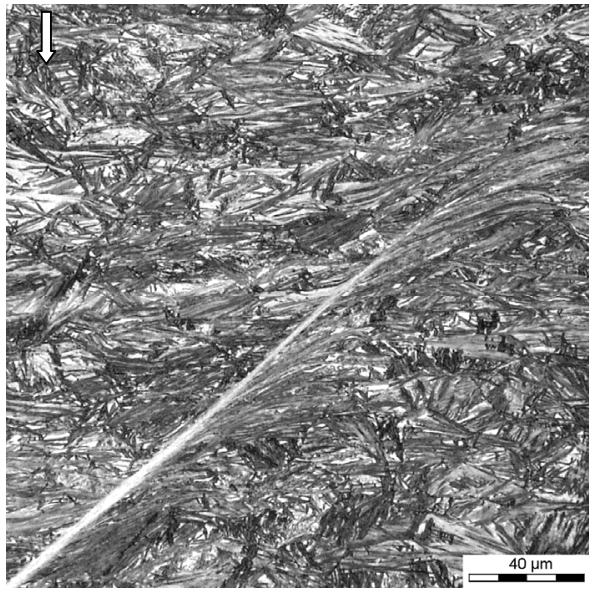

(c)

Fig. 8. Microstructure of the specimens after dynamic compression tests using SHPB. ITT $275^{\circ} \mathrm{C}$ variant: a) strain rate $5138 \mathrm{~s}^{-1}$, b) strain rate $\left.6585 \mathrm{~s}^{-1}, \mathrm{c}\right)$ strain rate $8999 \mathrm{~s}^{-1}$. Arrows indicate the compression direction

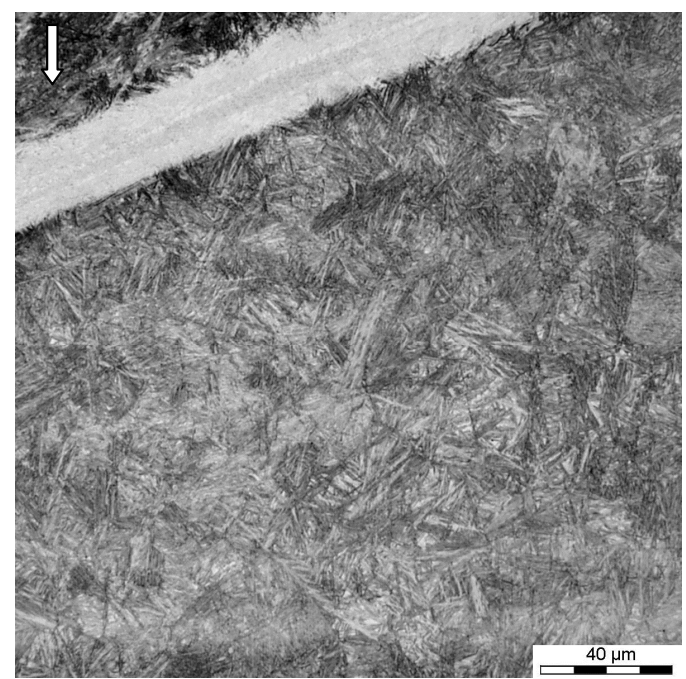

Fig. 9. Shear band due to ballistic impact. ITT $210^{\circ} \mathrm{C}$ variant, firing test (one shot), $0^{\circ}$ obliquity, projectile velocity (energy): $766 \mathrm{~m} / \mathrm{s} ;(2280 \mathrm{~J})$, arrow indicates the projectile direction

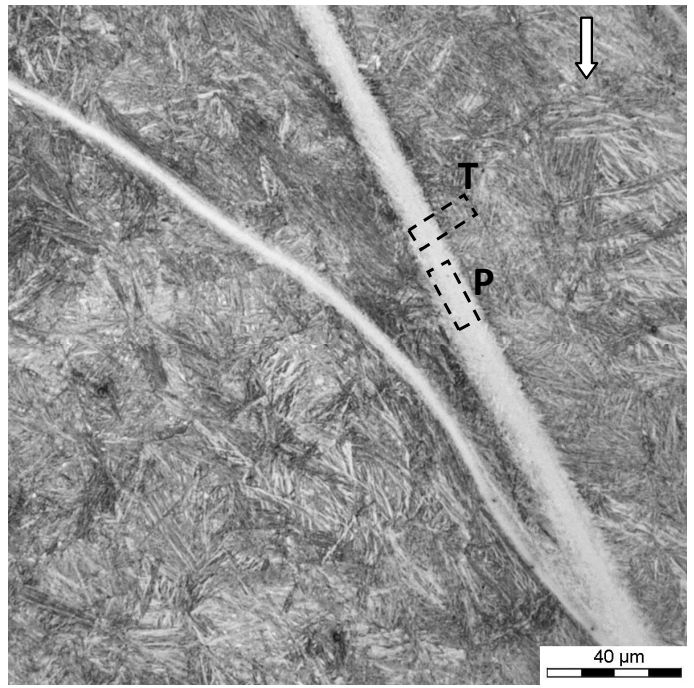

(a)

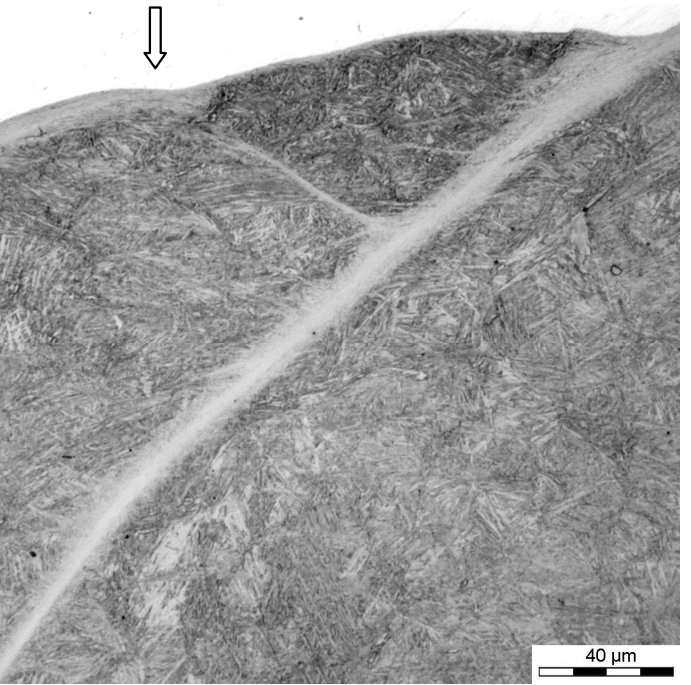

(b)

Fig. 10. Shear bands due to ballistic impact. ITT $210^{\circ} \mathrm{C}$ variant, firing test (one shot), $0^{\circ}$ obliquity, projectile velocity (energy): $929 \mathrm{~m} / \mathrm{s} ;(1536 \mathrm{~J})$, arrows indicate the projectile direction. On the micrograph (a), TEM specimens orientations were indicated: $\mathrm{T}-\operatorname{transverse,~} \mathrm{P}-$ parallel 


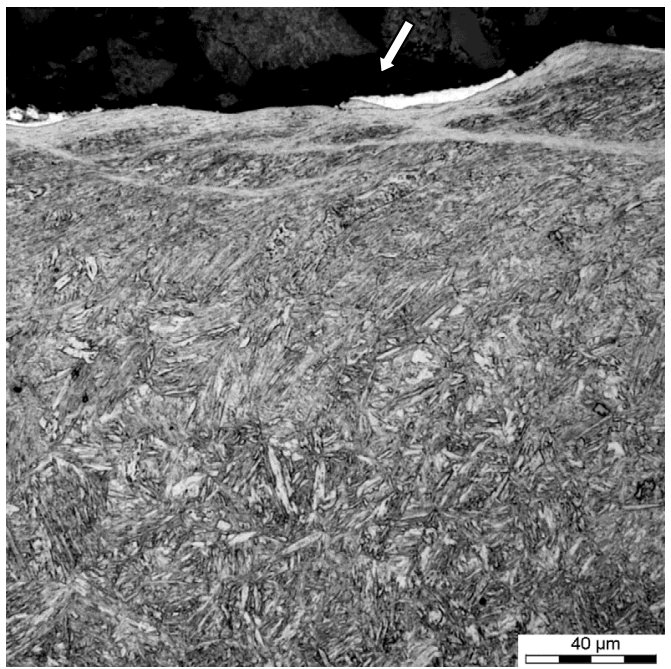

Fig. 11. Shear bands due to ballistic impact. ITT $210^{\circ} \mathrm{C}$ variant, firing test (multihit- 5 shots in one point), $30^{\circ}$ obliquity, projectile velocity (energy): $836-844 \mathrm{~m} / \mathrm{s} ;(3258-3319 \mathrm{~J})$, arrow indicates the projectile direction
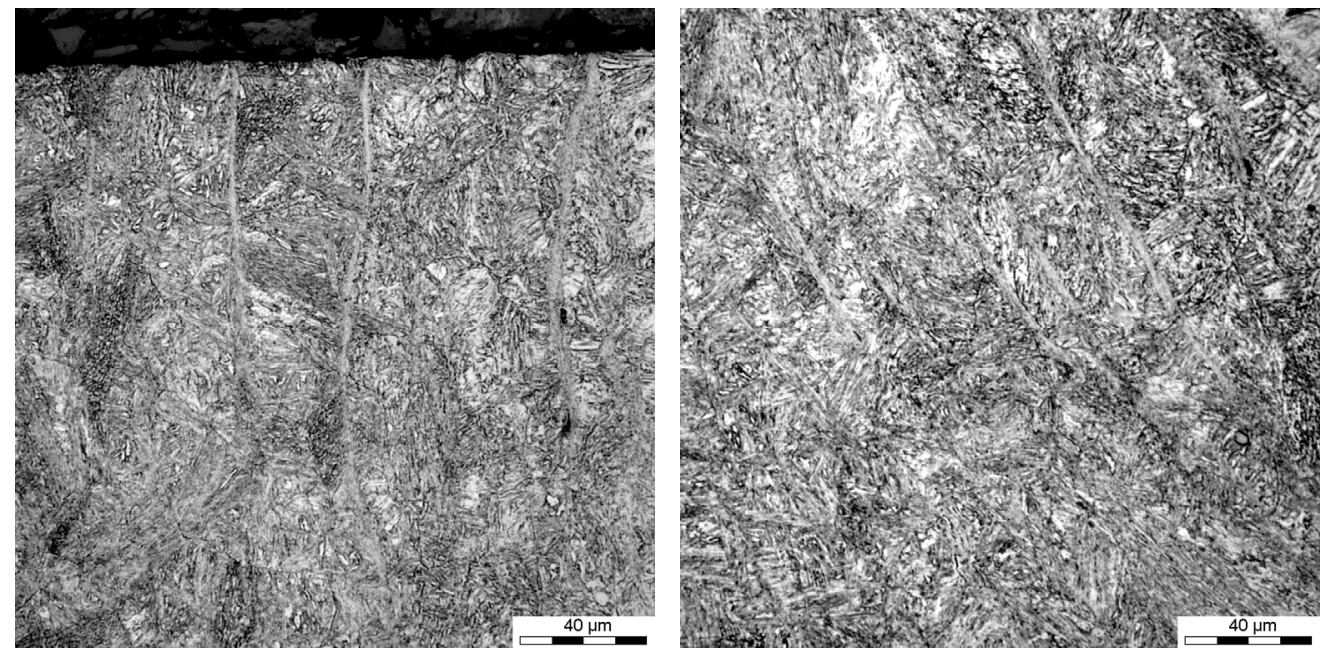

Fig. 12. Shear bands due to ballistic impact. ITT $210^{\circ} \mathrm{C}$ variant, firing test (multihit- 5 shots in one point), $30^{\circ}$ obliquity, projectile velocity (energy): $850-870 \mathrm{~m} / \mathrm{s} ;(3421-3577 \mathrm{~J})$, projectile direction into page

\subsection{Transmission electron microscopy}

Examination of ASB's is microstructure and microstructure of deformed material in the vicinity of the band were carried out on the transverse $(\mathrm{T})$ and parallel $(\mathrm{P})$ cross-sections taken from the area of the band. TEM specimens were extracted from the shear band using FIB equipment (Focused Ion Beam). Thin foil (T-lamella) was cut through the width of the band and covered matrix of the steel in the vicinity of the band. After examination of the T-specimen, next specimen was cut only from the central area of the ASB in the parallel direction to the band length (P-lamella). TEM specimens orientations were indicated on the micrograph in Fig. 10a.

Examined ASB of width c.a. $10 \mu \mathrm{m}$-visible in light microscope- consists of two regions of different microstructure: the core of the band and transition zone between the core and matrix of the steel (Figs. 13 and 14). The central equiaxed region (core) is flanked by a region of highly deformed and oriented lath-like structure-transition zone. The core of the shear band of width up to about $5 \mu \mathrm{m}$ consist of equiaxed extremely fine grains. The mean diameter of the grains is in the range of 100-200 nm (Figs. 15-17). Microdiffraction taken from the core of the band confirms only bcc structure (ferrite). No austenite or carbide reflections could be detected in the diffraction patterns taken from the regions showing the fine grains. The presence of new equiaxed fine grains and lack of retained austenite in the core of the shear band suggests that the laths of bainite could transformed to austenite during the shearing process. The microstructure within the equaixed region was examined at very high magnifications. A martensitic twins of width up to $10 \mathrm{~nm}$ of the orientation-zone axis [111] are noted within the fine grains (Figs. 18 and 19). Microdiffraction and HRTEM analysis of the core area of the band confirms only bec structure (ferrite) within the fine grains. In the transition zone of width about $8 \mu \mathrm{m}$ strongly deformed plates of bainite and film of retained austenite were found (Figs. 20 and 21). 


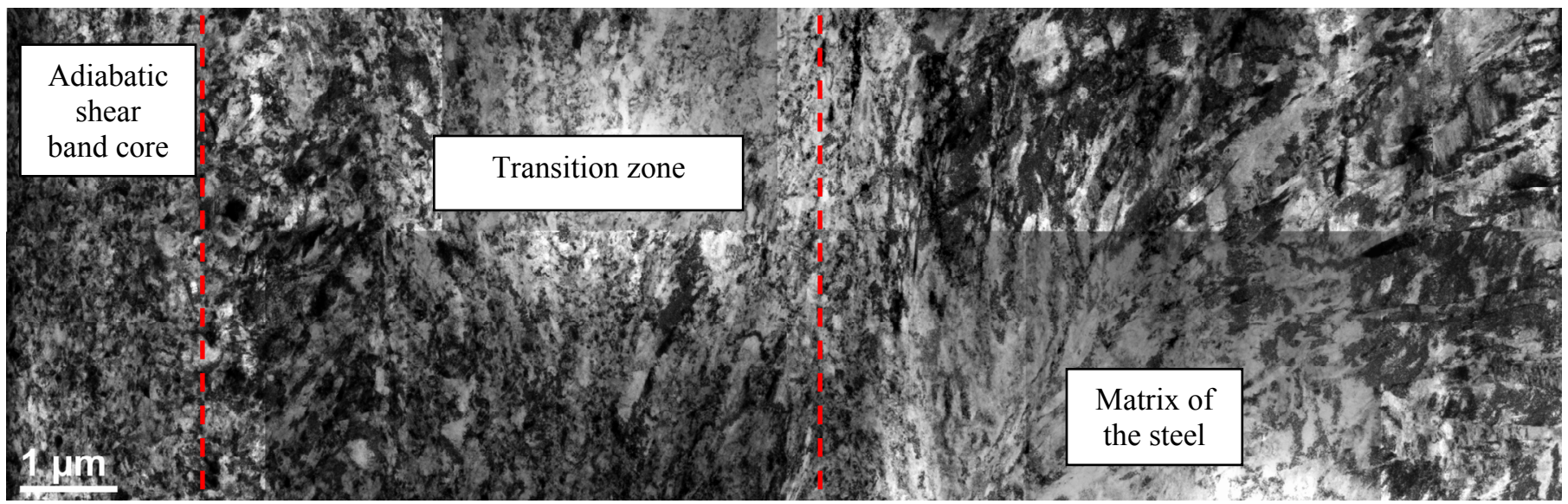

Fig. 13. Microstructure of the adiabatic shear band and matrix of the nanostructured bainitic steel in the vicinity of the band. ITT $210^{\circ} \mathrm{C}$ variant, transverse specimen $(\mathrm{T})$, bright field TEM image

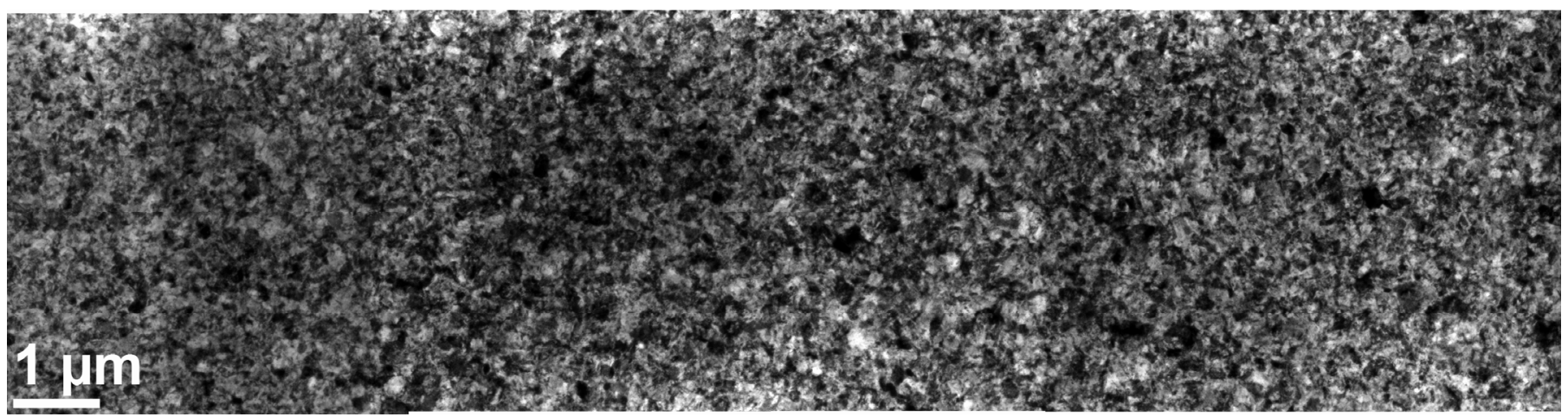

Fig. 14. Internal adiabatic shear band's microstructure (core). ITT $210^{\circ} \mathrm{C}$ variant, parallel specimen (P), bright field TEM image

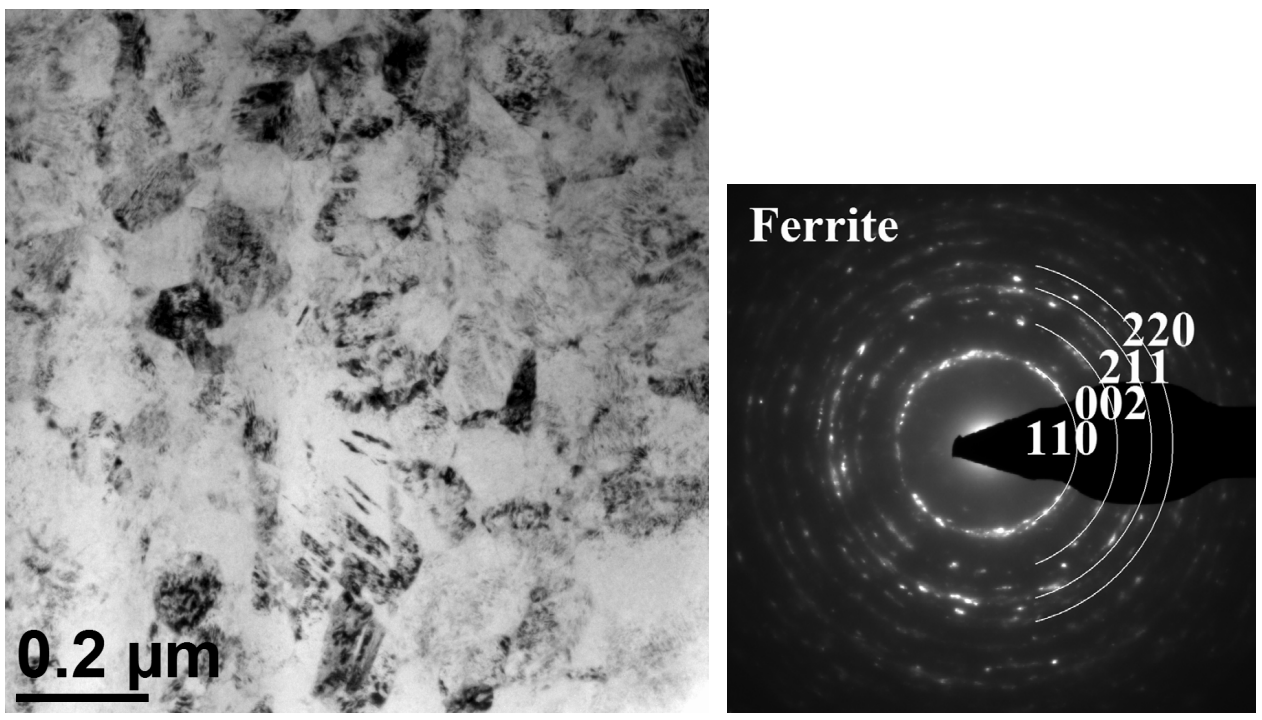

Fig. 15. Bright field TEM image of internal shear band microstructure (a) and electron diffraction pattern (b) taken with wide aperture, showing the limited spread of orientations in the shear band. ITT $210^{\circ} \mathrm{C}$ variant, transverse specimen $(\mathrm{T})$

\subsection{Hardness measurements of the deformed specimens}

Specimens after quasi-static and dynamic deformation were selected for the hardness measurements especially in the area of adiabatic shear bands and in the vicinity of the bands. Results of hardness measurements are shown in Table 5. Hardness of the specimens in the as-received condition was $610-630 \mathrm{HV}$ for ITT $210^{\circ} \mathrm{C}$ variant and $530-550 \mathrm{HV}$ for ITT $275^{\circ} \mathrm{C}$ variant.

Hardness of adiabatic shear bands for the ITT $210^{\circ} \mathrm{C}$ variant deformed quasi-statically and dynamically in Gleeble simulator was about $930 \mathrm{HV}$ and was independent on applied strain rate. 


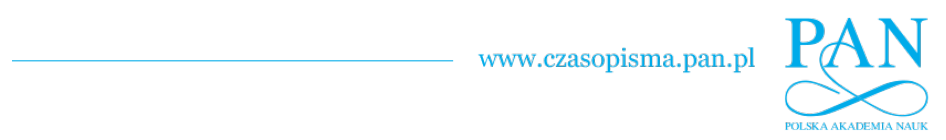

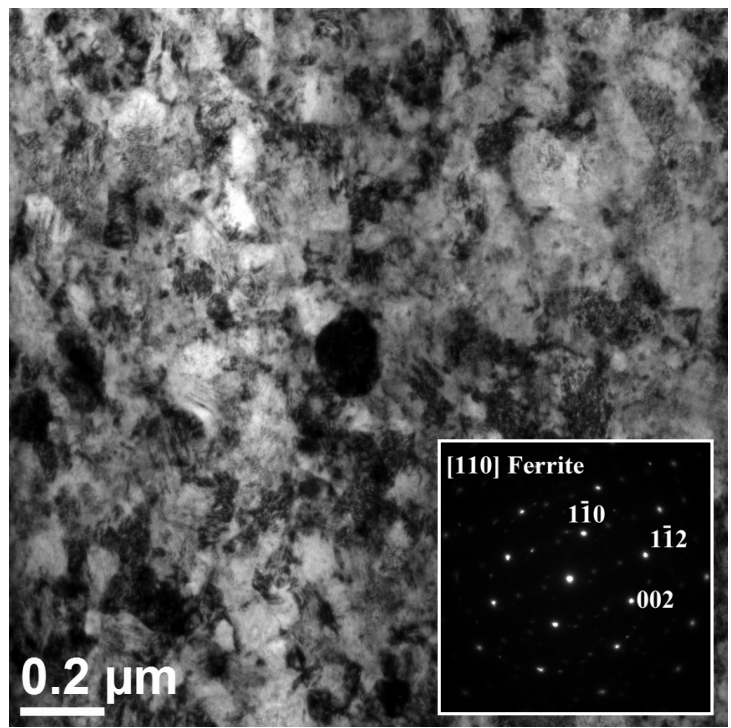

(a)

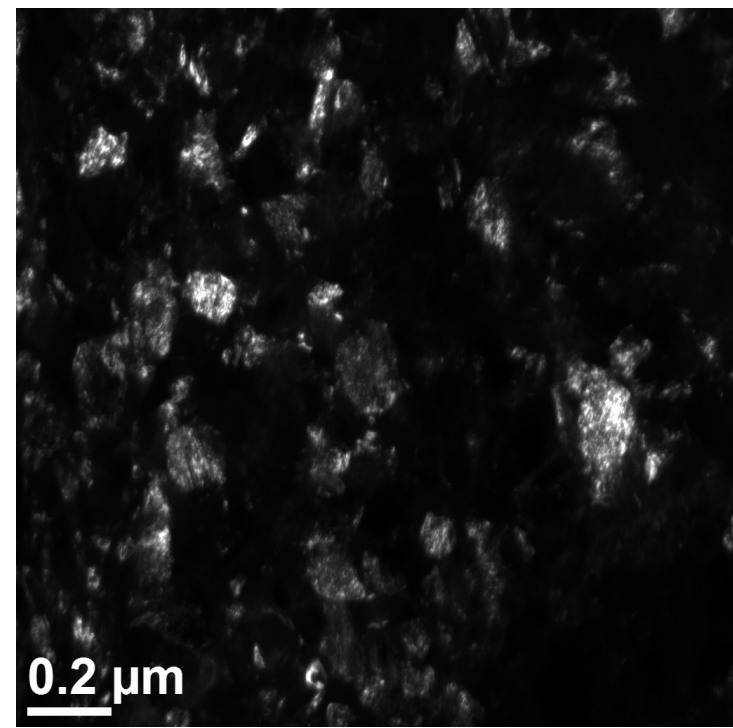

(b)

Fig. 16. Bright field TEM image (a), dark field TEM image in 110 reflection (b) of internal shear band microstructure and electron diffraction pattern for the zone axis [110] taken from core of the band. ITT $210^{\circ} \mathrm{C}$ variant, transverse specimen (T)

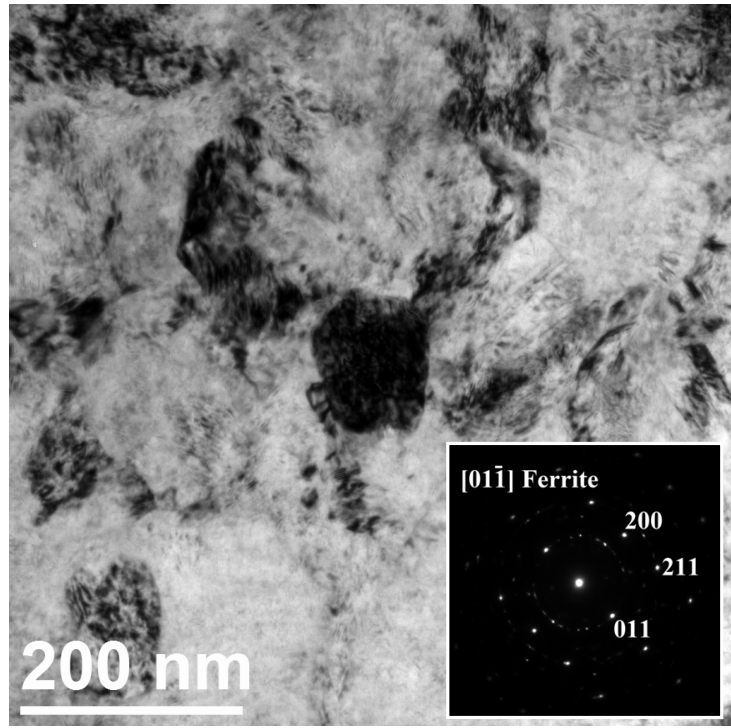

(a)

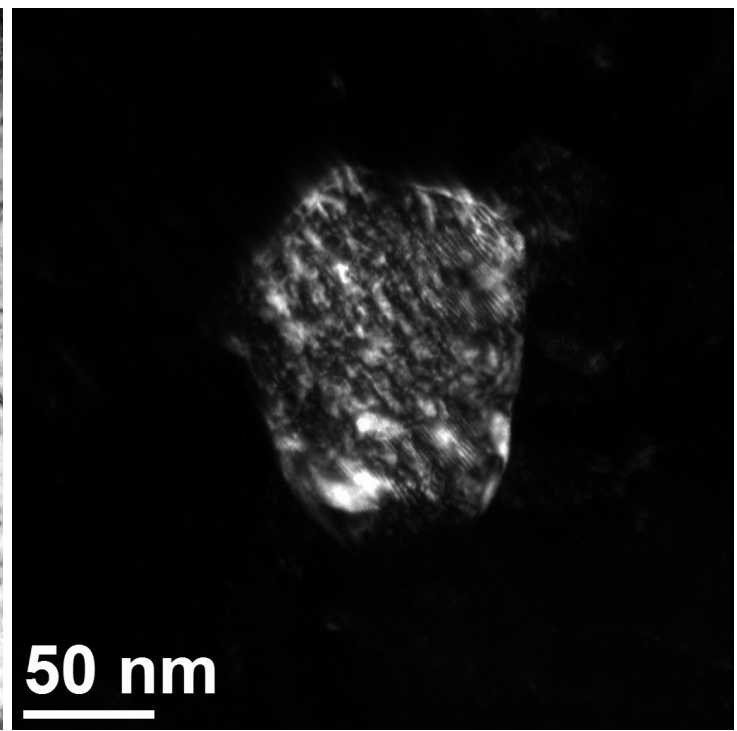

(b)

Fig. 17. Bright field TEM image (a), dark field image in 011 reflection (b) of internal shear band microstructure and electron diffraction pattern for the zone axis [01-1] taken from core of the band. ITT $210^{\circ} \mathrm{C}$ variant, parallel specimen $(\mathrm{P})$

Hardness of the matrix in the range 750-800 HV and 680-720 HV was determined for strain rate $0.5 \mathrm{~s}^{-1}$ and $200 \mathrm{~s}^{-1}$ respectively.

For ITT $275^{\circ} \mathrm{C}$ variant first adiabatic shear bands were detected during compression test in Gleeble at strain rate $200 \mathrm{~s}^{-1}$. Hardness of the bands reached maximum $890 \mathrm{HV}$ and hardness of the matrix was in the range of 600-690 HV. Hardness of the matrix of the variant ITT $275^{\circ} \mathrm{C}$ compressed at $0.5 \mathrm{~s}^{-1}$ was variable on the specimens length and reached maximum $720 \mathrm{HV}$ in the middle of the specimen (Fig. 22a).

Hardness of the ASBs in the specimens dynamically compressed using SHPB was 900-930 HV and 780-830 HV for ITT $210^{\circ} \mathrm{C}\left(4306 \mathrm{~s}^{-1}\right)$ and for ITT $275^{\circ} \mathrm{C}\left(8999 \mathrm{~s}^{-1}\right)$ variants respectively. ASBs were not detected in specimen of ITT $275^{\circ} \mathrm{C}$ variant compressed at strain rate up to $6585 \mathrm{~s}^{-1}$ the hardness of which was in the range of 620-660 HV on the entire specimen length (Fig. 22b).

Maximum hardness of ASBs was found in the specimen of ITT $210^{\circ} \mathrm{C}$ variant ballistically tested using projectile velocity $929 \mathrm{~m} / \mathrm{s}$ (kinetic energy $1536 \mathrm{~J}$ ). Hardness of the bands reached 960 HV (Fig. 23a). Transition zone between the core of the bands and the matrix of hardness range within 760-900 HV occurs (Fig. 23b). Matrix hardness outside near-to-surface dynamically deformed layer was the same as in as-received condition (610 HV). 


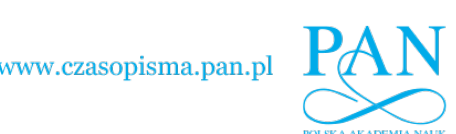

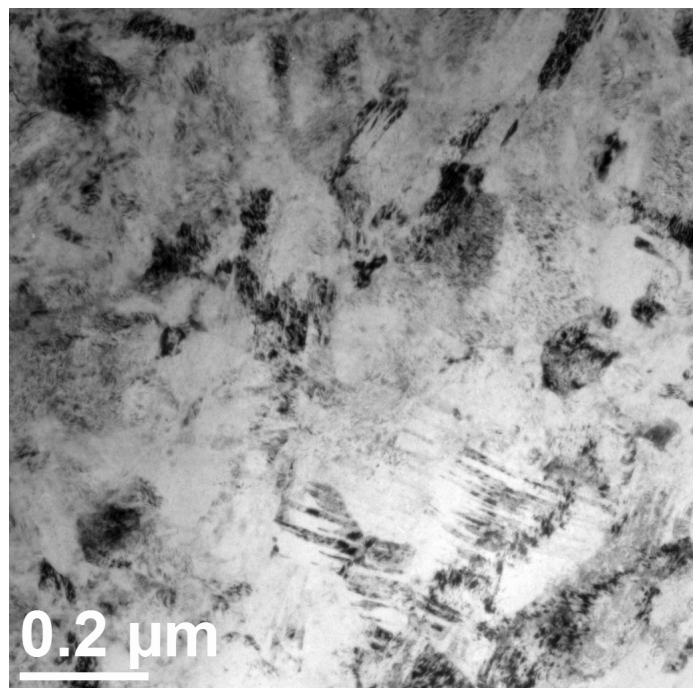

(a)

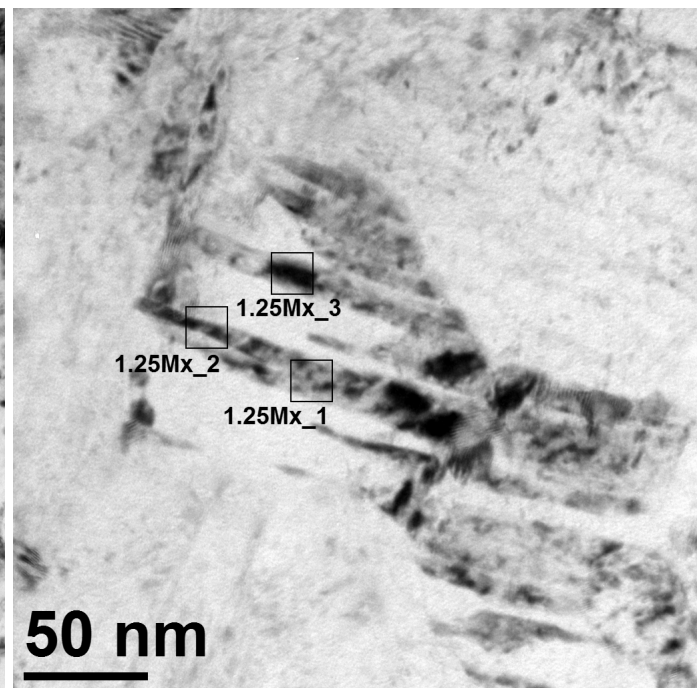

(b)

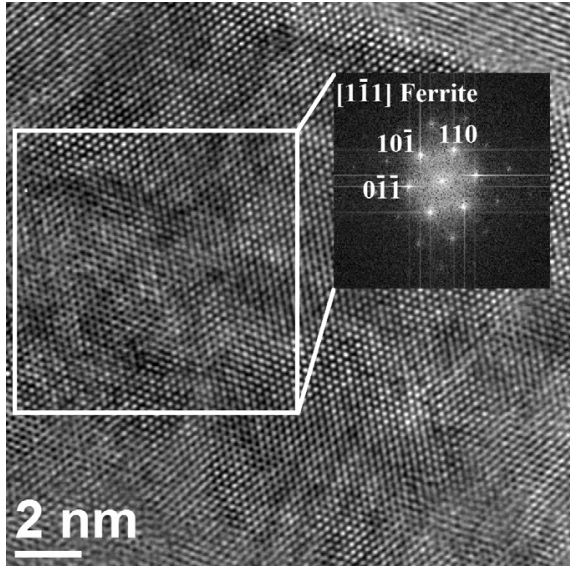

1

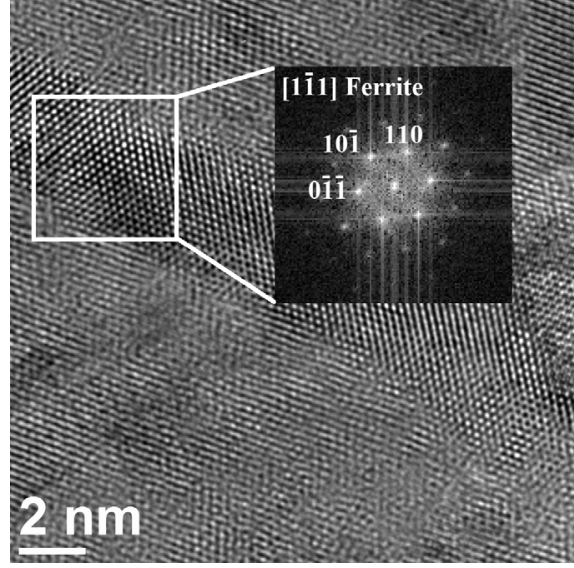

2

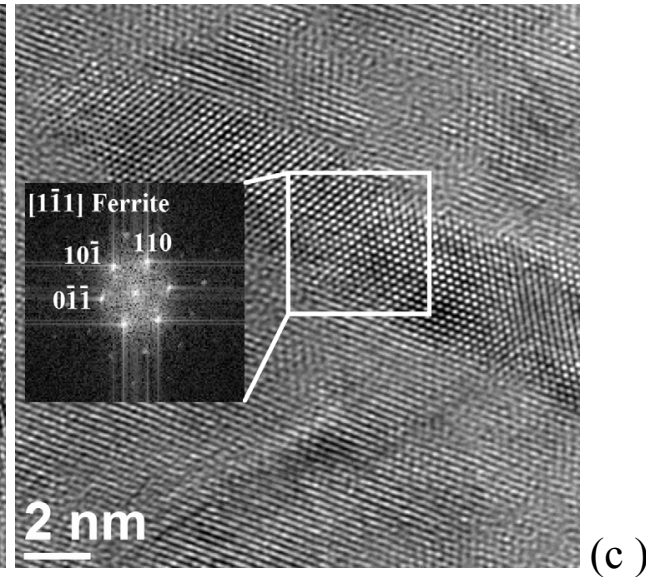

3

Fig. 18. Bright field TEM images of fine grains with martensitic twins within $(a, b)$ and high-resolution TEM images (HRTEM) depicting martensitic twins in fine grains in core of the band (c). ITT $210^{\circ} \mathrm{C}$, parallel specimen (P), areas 1,2 and 3 of HRTEM analysis were indicated on the micrograph (b)

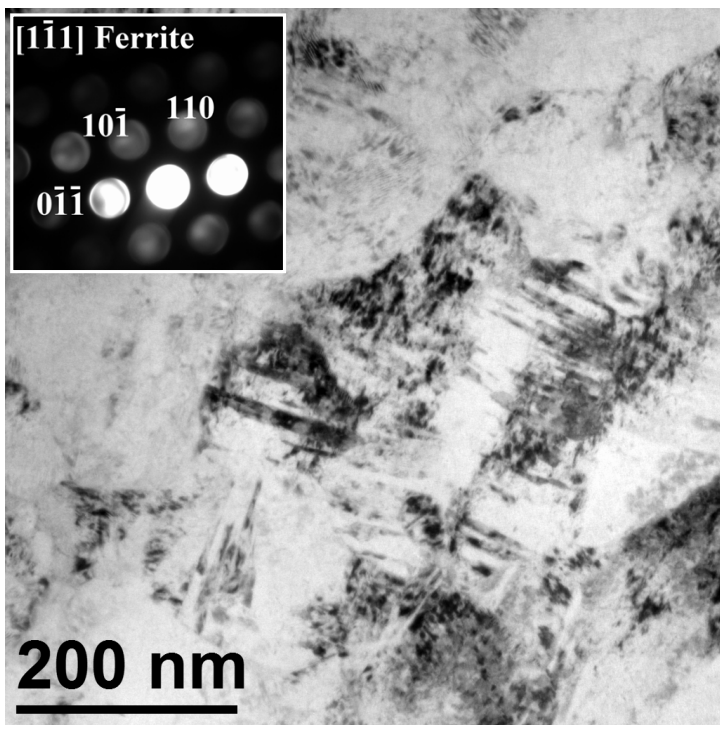

(a)

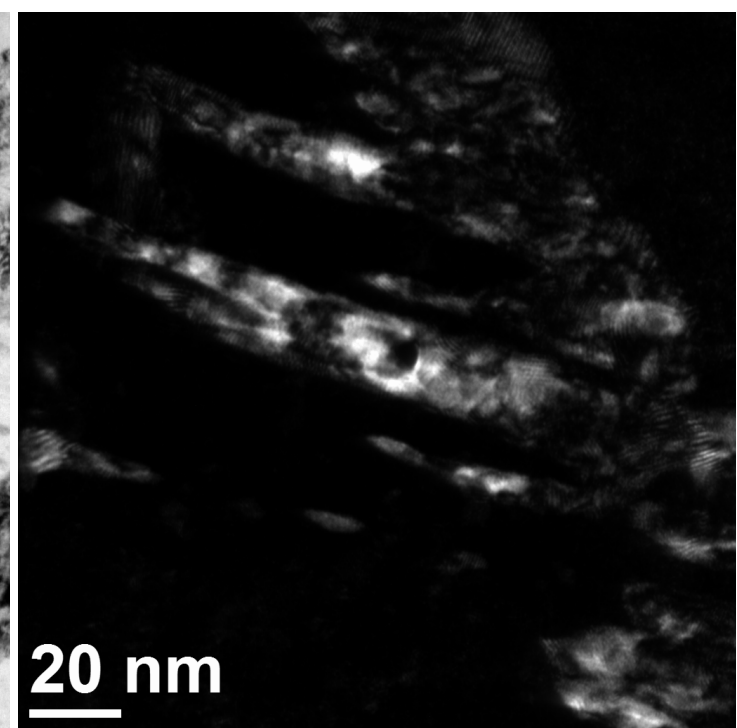

(b)

Fig. 19. Bright field TEM image (a), dark field TEM image in 011 reflection (b) of internal shear band microstructure and electron microdiffraction pattern for the zone axis [1-11] taken from twins in the core of the band. ITT $210^{\circ} \mathrm{C}$, parallel specimen $(\mathrm{P})$ 


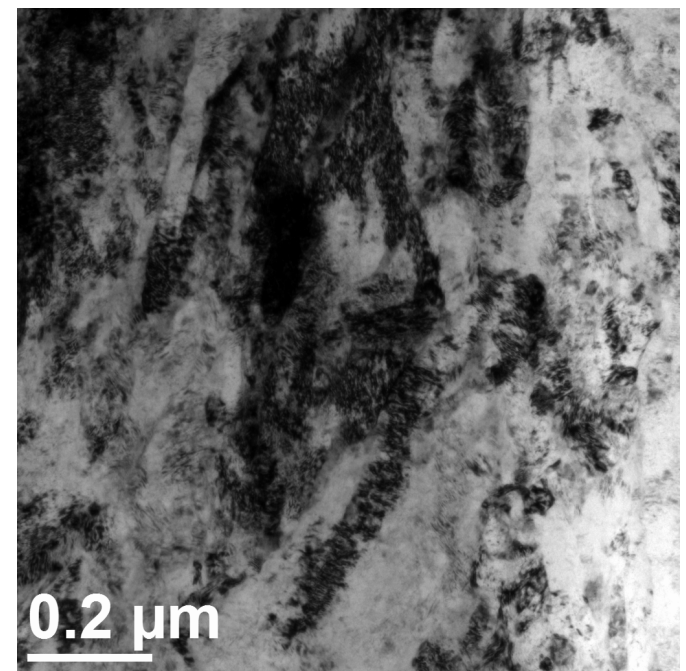

Fig. 20. Bright field TEM image in the area of transition zone between the core of the band and the matrix of the nanostructured steel

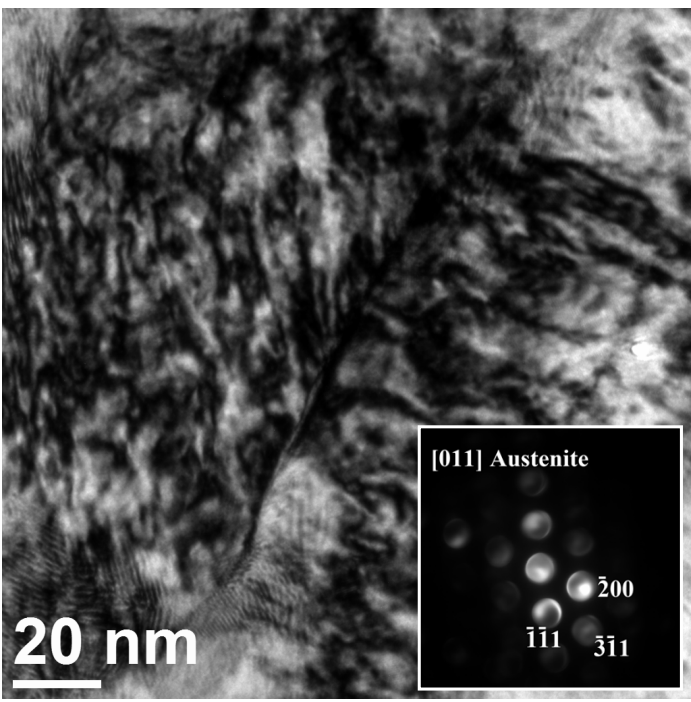

(a)

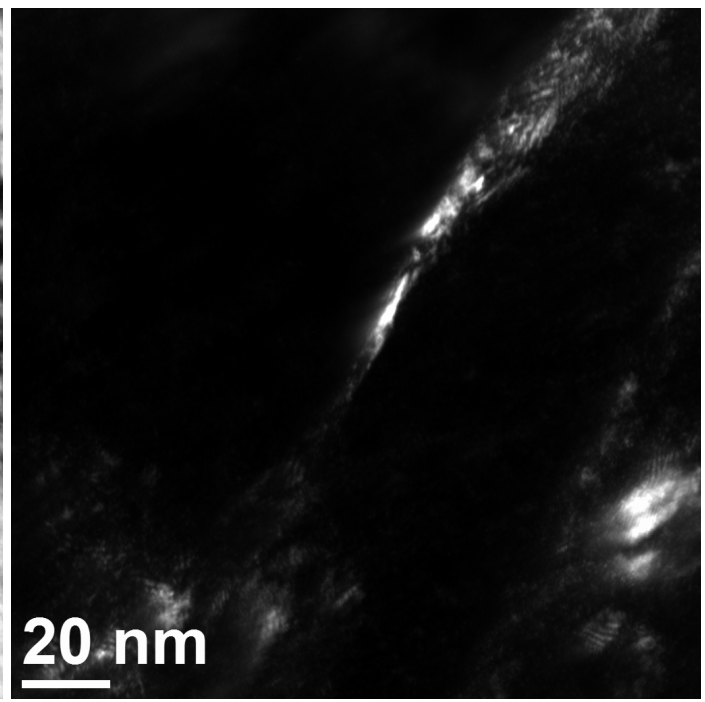

(b)

Fig. 21. Bright (a), dark (b) field TEM images and electron microdiffraction pattern for zone axis [011] taken from the austenite lath in the area of transition zone between the core of the band and the matrix of the nanostructured steel

\section{Discussion}

Results of examination of nanostructured bainitic steel after quasi-static and dynamic deformation using Gleeble simulator (strain rate up to $200 \mathrm{~s}^{-1}$ ) and Split Hopkinson Pressure Bar (strain rate up to $9 \times 10^{3} \mathrm{~s}^{-1}$ ) were presented. Moreover high energy firing tests of plates made of nanostructured bainitic steel were carried out and microstructural changes due to the tests were examined. Microstructure examination and hardness measurements were performed in the strain localization areas. Two variants of final heat treatment (isothermal transformation temperature-ITT: $210^{\circ} \mathrm{C}$ and $275^{\circ} \mathrm{C}$ ) different with strength (hardness), yield stress, total elongation and volume fraction of retained austenite were investigated.

ITT $210^{\circ} \mathrm{C}$ variant characterize by higher propensity to strain localization in form of ASBs during quasi-static and dynamic deformation experiments and in firing tests in comparison to ITT $275^{\circ} \mathrm{C}$ variant. Higher strain localization propensity was assessed on the basis of ASB's number and their width formed at different strain rates. ASBs of width up to $20 \mu \mathrm{m}$ visible in light microscope, formed during firing tests with $0^{\circ}$ obliquity for ITT $210^{\circ} \mathrm{C}$ variant in the near-to-surface layer of the plate under impact area. This thin layer is important in impact energy absorption process because hardness of the matrix outside deformed layer was not changed. It suggests that ASBs formation is high energy consumption process.

The TEM examination of the ASB showed the change from the internal shear band structure to the matrix structure to be gradual. Width of the examined ASB visible in light microscope was about $10 \mu \mathrm{m}$ and width of the core determined in TEM investigation was up to about $5 \mu \mathrm{m}$. This study clearly resolved that the interior (core) of the band has an extremely fine grained structure with grain diameter ranging from $100 \mathrm{~nm}$ to $200 \mathrm{~nm}$. Martensitic twins of the crystallographic orientation-zone axis 
Results of hardness measurement of the ASBs and the matrix of steel after quasi-static and dynamic deformation tests

\begin{tabular}{|c|c|c|c|}
\hline $\begin{array}{c}\text { Temperature of isothermal } \\
\text { heat treatment }\end{array}$ & $\begin{array}{c}\begin{array}{c}\text { Deformation } \\
\text { method }\end{array} \\
\end{array}$ & $\begin{array}{c}\text { Strain rate, test } \\
\text { parameters }\end{array}$ & Hardness of ASBs and deformed matrix \\
\hline $210^{\circ} \mathrm{C}$ & \multirow{4}{*}{$\begin{array}{l}\text { Uniaxial } \\
\text { compression } \\
\text { test in Gleeble } \\
\text { simulator }\end{array}$} & $0.5 \mathrm{~s}^{-1}$ & $\begin{array}{c}\text { ASB; HV0.010: 895, 932, 932, } 932 \\
\text { Matrix; HV1: 787, 769, 806, 794, 746, } 781\end{array}$ \\
\hline $210^{\circ} \mathrm{C}$ & & $200 \mathrm{~s}^{-1}$ & $\begin{array}{c}\text { ASB; HV0.025: 859, 926, 892, 870, 903, } 926 \\
\text { Matrix; HV1: 682, 702, 718, 714, 722, } 708\end{array}$ \\
\hline $275^{\circ} \mathrm{C}$ & & $0.5 \mathrm{~s}^{-1}$ & $\begin{array}{l}\text { No adiabatic shear bands were found } \\
\text { Hardness distribution (Fig. 22a) }\end{array}$ \\
\hline $275^{\circ} \mathrm{C}$ & & $200 \mathrm{~s}^{-1}$ & $\begin{array}{c}\text { ASB; HV0.025: 809, } 892 \\
\text { ASB; HV0.010: 828, 878 } \\
\text { Matrix; HV1: } 687,670,605,600\end{array}$ \\
\hline $210^{\circ} \mathrm{C}$ & \multirow{3}{*}{$\begin{array}{l}\text { Dynamic } \\
\text { compression } \\
\text { using SHPB }\end{array}$} & $4306 \mathrm{~s}^{-1}$ & $\begin{array}{c}\text { ASB; HV0.010: 901, 932, 896, } 895 \\
\text { Matrix; HV1: } 698,729,708,699,692\end{array}$ \\
\hline \multirow[b]{2}{*}{$275^{\circ} \mathrm{C}$} & & $6585 \mathrm{~s}^{-1}$ & $\begin{array}{c}\text { No adiabatic shear bands were found } \\
\text { Hardness distribution (Fig. 22b) }\end{array}$ \\
\hline & & $8999 \mathrm{~s}^{-1}$ & $\begin{array}{c}\text { ASB; HV0.010: } 792,802,778,813,813,833,807 \\
\text { In the vicinity of ASBs; HV0.010: 671, 672, } 663 \\
\text { Matrix; HV1: } 621,634,655\end{array}$ \\
\hline \multirow{2}{*}{$210^{\circ} \mathrm{C}$} & \multirow{2}{*}{$\begin{array}{l}\text { Firing test with } \\
0^{\circ} \text { obliquity }\end{array}$} & \multirow{2}{*}{$\begin{array}{l}929 \mathrm{~m} / \mathrm{s} \\
(1536 \mathrm{~J})\end{array}$} & Core of the ASB; HV0.025: 938, 950, 963 (Fig. 23a) \\
\hline & & & Transition zone; HV0.025: 914, 903, 828, 881, 763 (Fig. 23b) \\
\hline
\end{tabular}

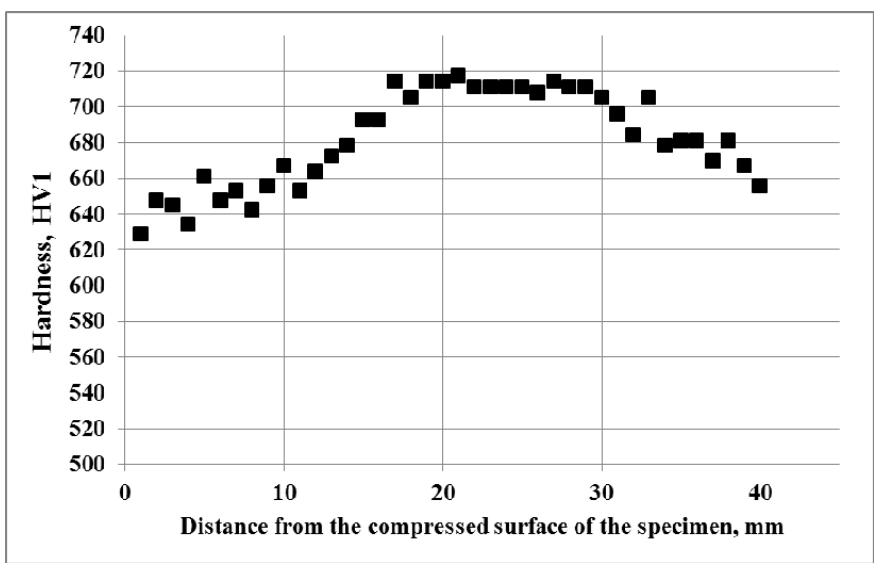

(a)

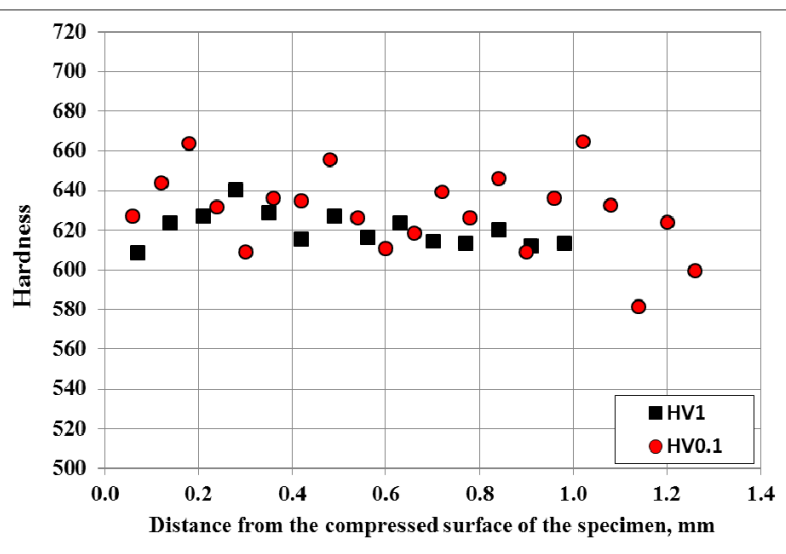

(b)

Fig. 22. Distribution of hardness in the length of specimen (ITT $275^{\circ} \mathrm{C}$ variant) deformed at strain rate $0.5 \mathrm{~s}^{-1}$ in Gleeble simulator (a) and at strain rate $6585 \mathrm{~s}^{-1}$ using SHPB (b). No adiabatic shear bands were found in both specimens

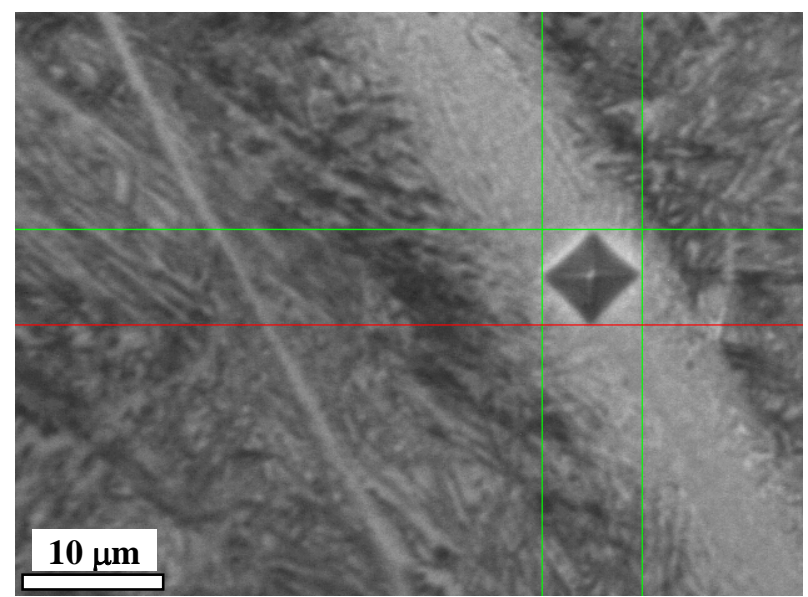

(a)

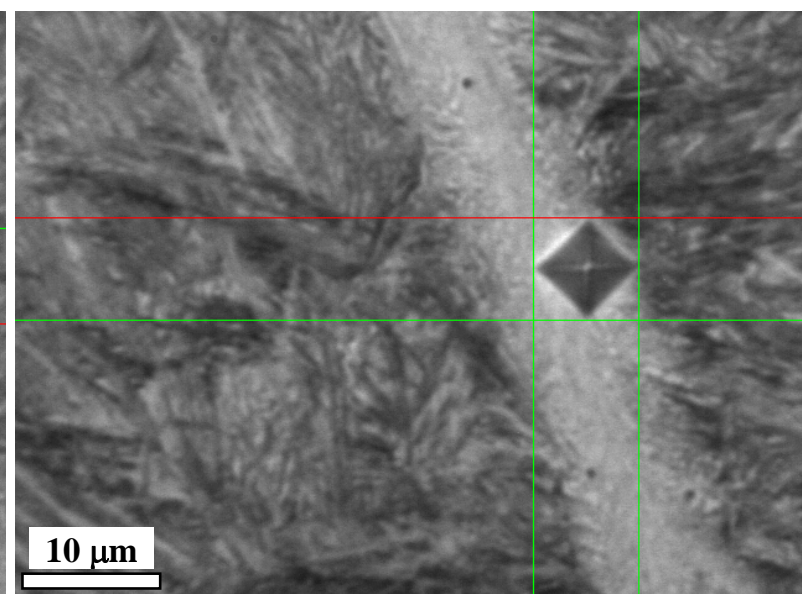

(b)

Fig. 23. Microstructure in the area of hardness measurement impressions. ITT $210^{\circ} \mathrm{C}$ variant after firing test $(\mathrm{V}=929 \mathrm{~m} / \mathrm{s} ; \mathrm{E}=1536 \mathrm{~J})$. (a) core of the band; (b) transition zone 
[111] were found within the grains. No austenite and carbide reflections were detected in the diffraction patterns taken from the core of the band. It suggests that phase transformation of carbide-free bainite laths into austenite has occurred and that the shear band has martensitic structure, in which both the extremely fine grain size with martensitic twins within combined with additional carbon in solution (from retained austenite) have increased the hardness of the band's core. Outside the core of the band the strongly deformed transition zone between the core and the matrix was found. The zone consists of carbide-free bainite laths and film of retained austenite.

For both examined variants of ITT similar increase in hardness of matrix in the range of 100-200 HV due to dynamic compression occurred. ASBs of hardness 930-960 HV were found in dynamically deformed material of ITT $210^{\circ} \mathrm{C}$ variant of hardness in as-received condition 610-630 HV. For second variant of ITT $275^{\circ} \mathrm{C}$ with hardness of $530-550 \mathrm{HV}$ in as-received condition, ASBs of hardness 830-890 HV occurred. Therefore hardness increase in ASBs of about $300 \mathrm{HV}$ referring to steel matrix hardness in as-received condition was determined.

\section{Conclusions}

ITT $210^{\circ} \mathrm{C}$ variant of nanostructured bainitic steel is susceptible to ASBs formation in quasi-static and dynamic compression. First ASB were detected for the ITT $210^{\circ} \mathrm{C}$ variant during compression test in Gleeble simulator at strain rate $0.5 \mathrm{~s}^{-1}$.

ASBs of width up to $20 \mu \mathrm{m}$ visible in light microscope, formed during firing tests with $0^{\circ}$ obliquity in the near-to-surface layer of the plate made of nanostructured bainitic steel of ITT $210^{\circ} \mathrm{C}$ variant.

First ASBs were detected for the ITT $275^{\circ} \mathrm{C}$ variant of the nanostructured steel during compression test using SHPB at strain rate $8999 \mathrm{~s}^{-1}$. This variant of final heat treatment is not prone to ASBs formation in dynamic compression.

In light microscope examination of specimen's microstructure after quasi-static and dynamic deformation ASBs were found of width ranging from few $\mu \mathrm{m}$ to maximum $20 \mu \mathrm{m}$ depending on ITT variant, strain rate and method of deformation.

TEM investigation showed that the interior (core) of the band has an extremely fine grained structure with grain diameter ranging from $100 \mathrm{~nm}$ to $200 \mathrm{~nm}$. Martensitic twins of width up to $10 \mathrm{~nm}$ were found within the grains. No austenite and carbide reflections were detected in the diffraction patterns taken from the core of the band.

Hardness of the core of the ASBs for examined variants of final heat treatment was higher about $300 \mathrm{HV}$ referring to steel hardness in as-received condition. Increase in hardness of matrix in the range of 100-200 HV due to dynamic compression occurred.

\section{Acknowledgements}

This work was financially supported by The National Centre for Research and Development (INNOTECH-K1/IN1/27/150443/NCBR/12, Project "Development of a modern armour panels resistant to the impact of shaped charges and projectiles")

\section{REFERENCES}

[1] F.G. Caballero, H.K.D. H. Bhadeshia, K.J.A. Mawella, D.G. Jones, P. Brown, Mater. Sci. Technol. 18, 279-284 (2002).

[2] C. Garcia-Mateo, F.G. Caballero, H.K.D.H. Bhadeshia, ISIJ Int. 43, 1238-1243 (2003).

[3] C. Garcia-Mateo, F.G. Caballero, H.K.D.H. Bhadeshia, ISIJ Int. 43, 1821-1825 (2003).

[4] F.G. Caballero, H.K.D.H. Bhadeshia, Curr. Opin. Solid State Mater. Sci. 8, 251-257 (2004).

[5] B. Garbarz, W. Burian, Steel Research Int. 85 (12), 1620-1628 (2014).

[6] A. Leiro, E. Vuorinen, K.G. Sundin, B. Prakash, T. Sourmail, V. Smanio, F.G. Caballero, C. Garcia-Mateo, R. Elvira, Wear, 298-299, 42-47 (2013).

[7] W. Liu, J. Qu, H. Shao, J. Mater. Proc. Technol. 69, 186-189 (1997).

[8] W. Burian, J. Marcisz, B. Garbarz, L. Starczewski, Arch. of Metall. and Mater. 59 (3), 1211-1216 (2014).

[9] J. Marcisz, W. Burian, J. Stępień, L. Starczewski, M. Wnuk, J. Janiszewski, 28th International Symposium on Ballistics, 13481361, 2014 Atlanta, USA.

[10] T.W. Wright, The physics and mathematics of adiabatic shear bands, Cambridge University Press, 2002.

[11] S.M. Walley, Metallurgical and Materials Transactions A 38A, 2629-2654 (November 2007).

[12] L.C.D. Fielding, H.K.D.H. Bhadeshia, Mater. Sci. and Tech. 30, 812-817 (2014).

[13] M.A. Meyers, V.F. Nesterenko, J.C. LaSalvia, Q. Xue, Mater. Sci. and Eng. A317, 204-225 (2001).

[14] B. Garbarz, J. Marcisz, W. Burian, A. Wiśniewski, Problemy Techniki Uzbrojenia. Biuletyn Naukowy Wojskowego Instytutu Technicznego Uzbrojenia, 118 (2), 41-49 (2011) (in polish).

[15] D.T. Chung, S.K. Moon, Y.H. Yoo, Journal de Physique IV, Colloque C8, supplement au Journal de Physique III 4, 547-552 (septembre 1994). 